This is the version of the article accepted for publication in International Journal of Transitional Justice published by Oxford University Press https://academic.oup.com/iiti

Accepted version downloaded from SOAS Research Online: http://eprints.soas.ac.uk/25747

\title{
What Women Want before Justice: Examining Justice Initiatives to Challenge Violence against Women in the DRC
}

Bilge Sahin and Sidonia Lucia Kula ${ }^{\dagger}$

\begin{abstract}
While the realization of women's rights has increased significantly in the Democratic Republic of the Congo, Congolese women's struggle is often obscured by certain international actors actively pushing for social change in the region. Those who are politically active in the area tend to forget that it is not the mere act of imposing policies that effects change, but rather actively involving Congolese women in decision-making processes. This article examines the way conflict-related sexual violence crimes are interpreted by donors, international organizations and international nongovernmental organizations, and what is implemented to challenge these acts of violence in accordance with the needs and expectations of Congolese women. By looking at current feminist discourse on conflict, security and development, the article aims to highlight the failures in implementing justice initiatives without input from women on the ground.
\end{abstract}

KEYWORDS: sexual and gender-based violence, sexual violence crimes in armed conflict, Democratic Republic of the Congo, African feminism

\section{INTRODUCTION}

Conflict-related sexual violence (CRSV) crimes have a long history in the Democratic Republic of the Congo (DRC). However, these crimes only became a focus point for national and international actors after peace agreements were signed following the two major wars in the DRC: the First Congo War of 1996/1997 and the Second Congo War from 1998 to

\footnotetext{
* PhD Candidate, Department of Development Studies, School of Oriental and African Studies (SOAS), University of London, UK. Email: bs42@soas.ac.uk

†PhD Candidate, School of Law, SOAS, University of London, UK. Email: s_luciakula@soas.ac.uk
} 
2003. ${ }^{1}$ UN campaigns such as UNiTE to End Violence against Women and the UN Security Council (UNSC) resolutions on women, peace and security ${ }^{2}$ provided a legal basis for the protection of women in armed conflict and triggered considerable international attention to CRSV crimes. Thus, with the end of the war in the DRC, both international and national actors' and communities' attention to CRSV crimes increased tremendously and these crimes became a significant focus for international assistance in the DRC.

This article examines the way CRSV crimes are interpreted by donors, international organizations and international nongovernmental organizations (INGOs) and what is implemented to challenge these acts of violence in accordance with the needs and expectations of Congolese women. It is necessary to reconceptualize how violence against women is interpreted given that gendered power relations between men and women continue to exist in legal and social structures, where violence and discrimination against women is still endemic due to the lack of state responsibility. ${ }^{3}$ Therefore, the aim is to understand whether the current international focus on CRSV crimes creates a response to what Congolese women need and expect, or whether it continues to produce gendered power relations. It is important to state that international actors are not the only agencies that frame the experience of Congolese women; the interaction between local and international patriarchies has certain impacts as well. However, due to the scope of this article, only the impact of international actors in the DRC is examined.

\footnotetext{
1 In 2002, the Pretoria Agreement was adopted, which determined a national reconciliation process and provided for the application of human rights through respect for international conventions such as the Universal Declaration of Human Rights, the International Pact on Civil and Political Rights (1966), the International Pact on Economic and Socio-Cultural Rights (1966), the African Charter on Human Rights and the Rights of Peoples (1981), and duly ratified international conventions. This facilitated the process for dealing with crimes committed during armed conflict, especially sexual violence crimes. See, B. Klosterboer and L. Hartmann-Mahmud, "'Difficult to Repair": Applying African Models for Transitional Justice to Peace and Restoration Prospects in the Democratic Republic of the Congo,' African Conflict and Peacebuilding Review 3(1) (2013): 56-80.

2 UN Docs. S/RES/1325 (2000) [hereinafter 'Resolution 1325'], S/RES/1820 (2008), S/RES/1888 (2009), S/RES/1889 (2009), S/RES/1925 (2010), S/RES/1960 (2010), S/RES/2106 (2013), S/RES/2122 (2013).

${ }^{3}$ Hilary Charlesworth and Christine Chinkin, The Boundaries of International Law: A Feminist Analysis (Manchester: Manchester University Press, 2000).
} 
The article is structured around an exploration of African feminist theory and how it might contribute to a better understanding and implementation of international policy. The study drew on the experiences of Congolese women living in the eastern DRC, where the conflict continues and international assistance is concentrated, as well as those who fled to Angola due to the ongoing conflict. Recognizing that Congolese women are not a homogeneous group, the data and arguments in this article in terms of Congolese women's needs and expectations are limited to the experiences of the study participants. Moreover, we refer to Congolese women exposed to CRSV crimes as 'survivors' rather than 'victims' to avoid conceptualizing women merely as victims and to recognize their agency.

\section{METHODOLOGY}

Data were collected through a literature review and interviews conducted by the authors. Semi-structured individual interviews were conducted with 36 international and local NGO officials, and Bilge Sahin organized focus group discussions for 29 Congolese women in North and South Kivu between October 2015 and January 2016. Additionally, Lucia Kula conducted research with 53 participants and used interviews, participant observation and life story collection techniques in Angola in 2016.

During our research and data collection process, we adhered to Raymond Lee and Claire Renzetti's definition of sensitive research areas as including those

(a) where research intrudes into the private sphere or delves into some deeply personal experience, (b) where the study is concerned with deviance and social control, (c) where it impinges on the vested interests of powerful persons or the exercise of coercion or domination. ${ }^{4}$

CRSV thus clearly qualified as a sensitive research topic, and we therefore followed stringent ethical guidelines during our research. Attention to the ethical concept of respect

\footnotetext{
${ }^{4}$ R.M. Lee and C.M. Renzetti, 'The Problems of Researching Sensitive Topics: An Overview and Introduction,' American Behavioral Scientist 33(5) (1990): 516.
} 
for persons emerged as crucial. As CRSV includes violation, we felt it was important not to replicate it within the research process but instead to create an equal and respectful environment. ${ }^{5}$ We thus applied several ethical requirements to the data collection process, such as informed consent, voluntariness, confidentiality and privacy. ${ }^{6}$

We applied due care in respect of confidentiality and privacy for the experiences of the research participants. Women who have been victimized have reason to fear further victimization and participating in research may put them at risk if their anonymity is violated. ${ }^{7}$ Accordingly, in this article we only reveal the identities of participants with their consent; otherwise, participants remain anonymous. We also applied due care when changing participants' names in order not to change important details such as gender, which might mislead the reader or distort the analysis.

The potential for retraumatization is a significant ethical concern in research into violence against women, ${ }^{8}$ and interviews may awaken memories of prior traumas. We tried to minimize potential harms by discussing and rewriting research questions with members of local NGOs and counsellors. Furthermore, Sahin always made sure that there was a counsellor who was familiar with the research participants in the interviews or focus groups

\footnotetext{
${ }^{5}$ L.A. Fontes, 'Ethics in Violence against Women Research: The Sensitive, the Dangerous, and the Overlooked,' Ethics and Behavior 14(2) (2004): 141-174.

6 See, World Health Organization, 'Ethical and Safety Recommendations for Researching, Documenting and Monitoring Sexual Violence in Emergencies,' 2007, http://www.who.int/gender/documents/OMS Ethics\&Safety10Aug07.pdf; 'Operational Guidelines for Institutional Review Boards,' https://www.moh.gov.sg/content/dam/moh web/Publications/Guidelines/Human\%20Biomedical\%20R esearch/2007/IRB\%20Operational\%20Guidelines 14-12-07 formatted.pdf (both accessed 3 April 2018). To gain the consent of participants working for international and national organizations and Congolese legal institutions, Sahin used consent forms in English and French. Considering the low levels of literacy in the research area, the authors did not use consent forms with local communities. Both authors instead received consent verbally from these communities as signed documents may have led to misunderstandings or mistrust towards the research. Potential participants might have thought they were signing a government document. Finally, for research participants who were minors, consent was received from their parents or legal guardians. In all cases, research participants gave consent for their narratives to be used in this article.

${ }^{7}$ L. Grauerholz, 'An Ecological Approach to Understanding Sexual Revictimization: Linking Personal, Interpersonal, and Sociocultural Factors and Processes,' Child Maltreatment 5(1) (2000): 5-17.

${ }^{8}$ J.C. Campbell and J.D. Dienemann, 'Ethical Issues in Research on Violence against Women,' in Sourcebook on Violence against Women, ed. C.M. Renzetti, J.L. Edleson and R.K. Bergen (Thousand Oaks, CA: Sage, 2001).
} 
who could intervene if the participants felt distressed. Sahin collected data from international organizations and INGOs in Goma using a snowballing technique and visited hospitals and legal aid clinics for on-site observations. The 29 participants for the four focus groups in South and North Kivu were recruited through a local NGO and legal aid clinic. Research participants' ages ranged from 14 to 61 . All were survivors of CRSV crimes and were receiving international assistance. The participants also knew each other and demonstrated comfort and trust while discussing their opinions and experiences. For survivors of CRSV crimes that were committed further back in time, focus groups are a suitable way to encourage participants to disclose behaviours and attitudes through their interactions with each other and thus obtain richer and more complex data that can begin to unravel takenfor-granted categories and beliefs. ${ }^{9}$ After the focus group discussions, the data were verified through counsellors and lawyers who were familiar with the research participants.

In addition, Kula collected data from 53 research participants ranging in age from 16 to 52. She used semi-structured interviews as they provide 'a way of generating empirical data about the social world by asking people to talk about their lives,' not only about their life events, but their points of view about everything within or outside their control. ${ }^{10}$ Kula conducted her interviews with the Congolese communities in Lunda Norte, Cabinda and Luanda (specifically in the neighbourhoods of Scongolense and Mabore). Research participants were contacted through registration centres, community spaces, churches, clinics and NGOs.

\section{UNDERSTANDING CRSV IN A WIDER CONTEXT}

In the literature, CRSV crimes are mainly referred to as wartime rape and described as a

\footnotetext{
${ }^{9}$ Frances Montell, 'Focus Group Interviews: A New Feminist Method,' NWSA Journal 11(1) (1999): 44-71.

10 J.A. Holstein and J.F. Gubrium, 'The Active Interview,' in Qualitative Research: Theory, Method and Practice, 2nd ed., ed. D. Silverman (London: Sage, 2004), 144.
} 
strategy of war and as a weapon which enables armed groups to achieve their military and political goals. ${ }^{11}$ This narrative limits the interpretation of CRSV crimes to contexts of armed conflict and does not fully take into account that rape is sometimes used as a violent instrument to socioeconomically disrupt and destabilize a community. Rape brings fear, threats and often leads people to move and become displaced. In regions where the exploitation of natural resources is a potential source of great wealth, this introduces significant socioeconomic motivations for CRSV. ${ }^{12}$

Jacqui True states that there is a lack of systematic gender analysis in academic literature to demonstrate the socioeconomic conditions which are created as a result of CRSV crimes. ${ }^{13}$ Any analysis that does not consider these conditions renders itself ineffective in conceptualizing the complexity of the relationship between gender, violence and socioeconomic structures. Hence, we examine CRSV crimes in a wider context to include their socioeconomic consequences. The analysis is structured around African feminist theory in order to understand gender, social and economic structures in an African context.

Nkolika Aniekwu reminds us that African feminism is different from its western counterparts, where discourse predominantly focuses on the female body, sexuality, autonomies and sexual rights, rather than on economic, social, cultural and political empowerment, as is the case with feminist discourse in other nonwestern regions. ${ }^{14}$ Similarly, Chandra Mohanty argues that in nonwestern contexts, women may experience the oppressive aspects differently despite the common complex of domination that all women

\footnotetext{
11 See, Dara K. Cohen, Amelia H. Green and Elisabeth J. Wood, 'Wartime Sexual Violence: Misconceptions, Implications, and Ways Forward,' US Institute of Peace Special Report 323 (2013); M. Eriksson Baaz and M. Stern, Sexual Violence as a Weapon of War? Perceptions, Prescriptions, Problems in the Congo and Beyond (London: Zed Books, 2013).

12 Meredeth Turshen, 'The Political Economy of Violence against Women during Armed Conflict in Uganda,' Social Research 67(3) (2000): 805-824.

13 Jacqui True, The Political Economy of Violence against Women (Oxford: Oxford University Press, 2012).

${ }^{14}$ Nkolika ljeoma Aniekwu, 'Converging Constructions: A Historical Perspective on Sexuality and Feminism in Post-Colonial Africa,' African Sociological Review 10(1) (2006): 143-160.
} 
face. ${ }^{15}$ Whilst this might be perceived as an essentialist narrative, and acknowledging that women in Africa deal with a multitude of problems, we concede that African feminism has strategic and political value. ${ }^{16}$

The perspective of African feminism provides a critical edge and scholarship to condition the experiences on the continent and to defy and challenge homogenizing descriptions, thus contributing to a recognition of gendered relations in the approach to violence and security. ${ }^{17}$ Josephine Ahikire states that in African contexts, feminism is at once philosophical, experiential, and practical. It informs women's-movement political strategy and practice on the continent, making it a very complex phenomenon to conceptualise.' 18 This is not to say that the African feminist challenge to policies and organizational cultures cannot be accepted as mainstream in the African public sphere. Akosua Ampofo and colleagues argue that African feminism and scholarship struggles with accepting concepts and scholarship produced in the global North and how these reflect on African realities. ${ }^{19}$ These western interventions and essentialist paradigms, as well as the approach to who and what is funded, can be perceived as generalizing and disadvantaging women's position and their agency. Conceptualizing the socioeconomic consequences that survivors of CRSV have to deal with in the DRC cannot therefore be held to an essentialist narrative, where the dominating discourse is unresponsive to the need to address

\footnotetext{
${ }^{15}$ Chandra Mohanty, 'Under Western Eyes: Feminist Scholarship and Colonial Discourses,' in Third World Women and the Politics of Feminism, ed. Chandra Mohanty, Ann Russo and Lourdes Torres (Bloomington, IN: Indiana University Press, 1991).

${ }^{16}$ Lilian Lem Atanga, 'African Feminism?' in Gender and Language in Sub-Saharan Africa: Tradition, Struggle and Change, ed. Lilian Lem Atanga, Sibonile Edith Ellece, Lia Litosseliti and Jane Sunderland (Amsterdam: John Benjamins, 2013).

17 Bagele Chilisa and Gabo Ntseane, 'Resisting Dominant Discourses: Implications of Indigenous, African Feminist Theory and Methods for Gender and Education Research,' Gender and Education 22(6) (2010): 617-632.

18 Josephine Ahikire, 'African Feminism in Context: Reflections on the Legitimation Battles, Victories and Reversals,' Feminist Africa 19 (2014): 8.

${ }^{19}$ Akosua Adomako Ampofo, Josephine Beoku-Betts and Mary J. Osirim, 'Researching African Women and Gender Studies: New Social Science Perspectives,' African and Asian Studies 7(4) (2008): 327-341.
} 
marginalized women's position in the global South. ${ }^{20}$

In conflict settings, due to ethnicity, economic status and societal dynamics, Congolese women deal with various consequences. When an analysis of CRSV and its wider consequences fails to address these social, economic and political dimensions, it can contribute to misleading and contextually inappropriate advocacy interventions on behalf of local women. ${ }^{21}$ Thus, it is important to analyze what Congolese women experience as a result of CRSV in a wider context.

Firstly, survivors of sexual violence crimes suffer from physical injuries as a result of the violence. Many women survivors have medical problems related to internal tearing and severe fistula. Some of the injuries can be fatal, depending on the age of the survivor and the brutality of the act of violence. Also, HIV and other sexually transmitted diseases are frequently spread through these acts of sexual violence. Moreover, sexual violence incidents increase the risk of unwanted pregnancies. ${ }^{22}$

Psychological traumas are another consequence of sexual violence crimes in armed conflict in the eastern DRC. Years after the events, survivors may still suffer from the psychological consequences of the trauma they experienced. Fear dominates the daily life of most survivors, causing constant torment, mental anguish and psychological stress and damage..$^{23}$

Furthermore, due to gendered power relations, survivors of these acts of violence face the risk of stigmatization and exclusion from their families and society, which leads to their alienation from community and public life. In the eastern DRC, where a woman's value

20 Judy El-Bushra, 'Feminism, Gender, and Women's Peace Activism,' Development and Change 38(1) (2007): 131-147.

${ }^{21}$ Patricia H. Collins, 'Gender, Black Feminism, and Black Political Economy,' Annals of the American Academy of Political and Social Science 568(1) (2000): 41-53.

${ }^{22} \mathrm{M}$. Bosmans, 'Challenges in Aid to Rape Victims: The Case of the Democratic Republic of the Congo,' Essex Human Rights Review 4(1) (2007): 1-12.

${ }^{23}$ C. Clifford, 'Rape as a Weapon of War and its Long-Term Effects on Victims and Society' (presented at the 7th Global Conference on Violence and the Contexts of Hostility, Budapest, Hungary, 5-7 May 2008). 
is associated with marriage and childbearing, incidents of sexual violence are often interpreted as acts that dishonour and humiliate the husband, family and community, and women are seen as 'tarnished' or 'spoiled. ${ }^{24}$ Furthermore, society assumes that a woman should protect herself from sexual violence crimes perpetrated by a man other than her husband. Her failure to do so is interpreted as her having allowed herself to be subjected to sexual violence.

Given that societal norms of womanhood, motherhood and marriage affect women's position in their communities, CRSV crimes can lead to social exclusion and economic deprivation. Survivors of such crimes are economically disadvantaged by social exclusion. When they are rejected by their families and communities, they usually do not have any economic means to support themselves. Women suffer due to a lack of education and limited access to economic freedom, which makes them more vulnerable when they lack the support of their husbands and families. Moreover, access to agricultural production ceases due to the ownership of land being monopolized in the hands of men. ${ }^{25}$ Furthermore, injuries from CRSV incidents further problematize access to paid work. Girl survivors of CRSV usually have to discontinue their education due to ill-health, trauma, displacement or stigma, thus erasing prospective career opportunities. ${ }^{26}$ An expert working for an international organization in Goma stated that 'when a girl is raped, her father will not pay for her school and he does not want to make an investment for that girl because no one will marry her anymore. ${ }^{27}$ Such young women and girls are thus no longer seen as worthy of any investment in their future. Given that economic self-sufficiency is linked to Congolese women's position within their communities, the political and economic consequences of

\footnotetext{
${ }^{24}$ K.T. Hagen and S.C. Yohani, 'The Nature and Psychosocial Consequences of War Rape for Individuals and Communities,' International Journal of Psychological Studies 2(2) (2010): 14-25.

25 True, supra $\mathrm{n} 13$

26 Human Rights Watch, 'Soldiers Who Rape, Commanders Who Condone: Sexual Violence and Military Reform in the Democratic Republic of Congo,' 2009, https://www.hrw.org/report/2009/07/16/soldiers-who-rape-commanders-who-condone/sexualviolence-and-military-reform (accessed 3 April 2018).

${ }^{27}$ Sahin interview, expert from an international organization, North Kivu, the DRC, 27 October 2015.
} 
CRSV are thus intractably connected.

Therefore, medical issues and socioeconomic dynamics need to be included in the interpretation of CRSV crimes and their consequences for female survivors. Exclusion of such aspects from international assistance in challenging CRSV crimes in the DRC will fail to comprehensively deal with what Congolese women's problems are and how to provide an effective solution to combat violence against them.

\title{
INTERNATIONAL ACTORS' INTERPRETATION OF CRSV IN THE DRC
}

International actors generally conceptualize CRSV crimes as a security issue. ${ }^{28}$ Thus, the policies and projects to challenge these acts of violence are shaped in accordance with this dominant discourse. While security used to be defined from a state-centric perspective, since the 1990s it has been understood as 'human security,' which champions the human over the state when the interests of the state and its populations differ. ${ }^{29}$ The UN definition of human security states that,

\begin{abstract}
Human security means protecting fundamental freedoms - freedoms that are the essence of life. It means protecting people from critical (severe) and pervasive (widespread) threats and situations. It means using processes that build on people's strengths and aspirations. It means creating political, social, environmental, economic, military and cultural systems that together give people the building blocks of survival, livelihood and dignity. ${ }^{30}$
\end{abstract}

This definition intentionally leaves out women as a special concern and instead claims that the concept encompasses all inequalities. However, women's security and men's security are not identical and there is a need to acknowledge what human security means

\footnotetext{
28 UN Docs., supra n 2.

29 B. Hettne, 'Development and Security: Origins and Future,' Security Dialogue 41(1) (2010): 31-52.

${ }^{30}$ Commission on Human Security, Human Security Now (2003), 4.
} 
for women and what constitutes violence against women. ${ }^{31}$ Furthermore, while the insecurities of women and men are diverse, the security needs of women in the global North are also different from those of women in the global South. ${ }^{32}$ Specifically, African feminism explains that being a woman in Africa is affected not by "bourgeois individualism and the patriarchal control over women within capitalist industrialising societies,' as in the global North, but by 'a history of a female integration within agrarian based societies with strong cultural heritages that have experienced traumatic colonization by [the] West. ${ }^{33}$ Thus, in accordance with the historical, political, economic, social and cultural diversities at regional, national and even local levels, the experiences of women are differentiated. Considering this, in respect of an expanded human security concept, a feminist perspective highlights the dangers of masking differences under the category of the term 'human.'

Nevertheless, human security creates an attractive normative framework for feminists due to its focus on the impact of insecurities on people and the agency of those affected by insecurity. ${ }^{34}$ In this respect, in terms of women's rights, human security discourse facilitates acknowledgement of the ways in which war and armed conflict affect women differently according to the power they have and their constructed roles within society. ${ }^{35}$

Specifically, at a policy level, UN documents use the language of human security to

\footnotetext{
${ }^{31}$ Fionnuala Ní Aoláin, 'Women, Security, and the Patriarchy of Internationalized Transitional Justice,' Human Rights Quarterly 31(4) (2009): 1055-1085; A.M. Tripp, 'Toward a Gender Perspective on Human Security,' in Gender, Violence and Human Security: Critical Feminist Perspectives, ed. A.M. Tripp, M.M. Ferree and C. Ewig (New York: New York University Press, 2013).

$32 \mathrm{H}$. Hudson, "'Doing" Security as though Humans Matter: A Feminist Perspective on Gender and the Politics of Human Security,' Security Dialogue 36(2) (2005): 155-174; J.A. Tickner, 'Feminist Perspectives on Security in a Global Economy,' in Globalization, Human Security and the African Experience, ed. C. Thomas and P. Wilkin (Boulder, CO: Lynne Rienner, 1999).

33 G. Mikell, 'Introduction: The Crisis of Gender and State,' in African Feminism: The Politics of Survival in Sub-Saharan Africa, ed. G. Mikell (Philadelphia, PA: University of Pennsylvania Press, 1997), 4.

${ }^{34}$ L. Sjoberg, 'Introduction,' in Gender and International Security: Feminist Perspectives, ed. L. Sjoberg (Abingdon: Routledge, 2010); L.J. Shepherd, 'Power and Authority in the Production of United Nations Security Council Resolution 1325,' International Studies Quarterly 52(2) (2008): 383404; V. Taylor, 'From State Security to Human Security and Gender Justice,' Agenda: Empowering Women for Gender Equity 59 (2004): 65-70.

${ }^{35}$ R. Christie, 'Critical Voices and Human Security: To Endure, to Engage or to Critique?' Security Dialogue 41(2) (2010): 169-190.
} 
draw attention to the ways in which women suffer in armed conflict. ${ }^{36}$ The UNSC's adoption of Resolution 1325 in 2000 provided a legal basis for the protection of women in armed conflict within the international communities' objectives, and prioritized CRSV as a security threat. After the implementation of that resolution, from 2008 onwards the UNSC adopted six more resolutions on women, peace and security ${ }^{37}$ which strengthen the discourse on CRSV crimes and security narratives.

However, feminist approaches emphasize that it is not enough to incorporate women into discussions of security; it is equally important to examine how women are incorporated. The main concern of international communities is women's 'vulnerability' and their 'need for protection' during armed conflict. ${ }^{38}$ However, while women are largely represented as 'victims,' their agency is acknowledged during the peacebuilding process, which requires support and empowerment from outside. ${ }^{39}$ Therefore, while women's insecurities are acknowledged, they continue to be defined as vulnerable and powerless. This essentialist approach shapes international actors' policies and projects, which in turn influences the way they deal with CRSV crimes. Unfortunately, the DRC is no exception.

Although human security led to CRSV crimes being acknowledged by international actors, the interpretation of said crimes as simply a security issue is problematic. This can be observed in the solutions provided by international actors in order to deal with security problems, such as an improvement of state capacity and strengthening state institutions to challenge CRSV crimes. ${ }^{40}$ When the state is developed enough, it is expected to challenge

\footnotetext{
${ }^{36}$ The UNDP's 1994 Human Development Report, which can be used as a guideline for human security, includes the need to consider the security needs of women and necessitates a pro-women approach in security. See, UNDP, 'Human Development Report 1994: New Dimensions of Human Security,' http://hdr.undp.org/sites/default/files/reports/255/hdr_1994_en_complete_nostats.pdf (accessed 3 April 2018).

37 UN Docs., supra $\mathrm{n} 2$.

$38 \mathrm{lbid}$.

39 D. Otto and G. Heathcote, 'Rethinking Peacekeeping, Gender Equality and Collective Security: An Introduction,' in Rethinking Peacekeeping, Gender Equality and Collective Security, ed. D. Otto and G. Heathcote (Hampshire: Palgrave Macmillan, 2014).

${ }^{40}$ M. Duffield, 'Global Civil War: The Non-Insured, International Containment and Post-Interventionary Society,' Journal of Refugee Studies 21(2) (2008): 145-165.
} 
violence and provide peace. However, explaining CRSV crimes through security discourse, coupled with the common lack of state authority in these conflict regions, ignores who is threatened, the source of the threat and the heinous nature of the crimes. Moreover, the contingent factors of CRSV, or targeting specific predictors of violence, are excluded from the solutions to these crimes. ${ }^{41}$ Also, the interventions continue to be top-down rather than engaging with the lived experiences of women. ${ }^{42}$

Due to the security and state capacity discourse, gender, economic and social relations are seen as unimportant, unfamiliar and unmanageable ways to challenge CRSV crimes. ${ }^{43}$ However, CRSV crimes are affected by these contexts. Gender power relations, women's traditionally appointed responsibilities, their social and economic status and ability to access resources all have an impact on the violence that women experience in conflict settings. The consequences that women face as a result of CRSV crimes also derive from gendered and socioeconomic disruptions within the cultural context. Without this balanced approach and complex assessment of women's rights, state institutions do not possess adequate tools to challenge CRSV crimes. A grounded analysis of the socioeconomic consequences of violence is important in a context where development and security agendas are pushed as a tool to tackle women's 'vulnerability' and their 'need for protection' during armed conflict. Liz Kelly states that 'a peace meaningful to women would require not just the absence of armed and gender conflict at home, locally and abroad, but also the absence of poverty and the conditions which recreate it. ${ }^{34}$ Therefore, while human security facilitates acknowledgement of CRSV crimes, the limited definition focusing on security and state capacity, as well as the essentialist approach towards women's experience and

\footnotetext{
41 True, supra $\mathrm{n} 13$.

${ }^{42}$ Shepherd, supra n 34; G. Hoogensen and K. Stuvøy, 'Gender, Resistance and Human Security,' Security Dialogue 37(2) (2006): 207-228.

$43 \mathrm{~S}$. Autesserre, The Trouble with the Congo: Local Violence and the Failure of International Peacebuilding (Cambridge: Cambridge University Press, 2010).

${ }^{44}$ L. Kelly, 'Wars against Women: Sexual Violence, Sexual Politics and the Militarised State,' in States of Conflict: Gender, Violence and Resistance, ed. S. Jacobs, R. Jacobson and J. Marchbank (London: Zed Books, 2000), 49.
} 
agency, together pave the way for the reproduction of gendered power relations. This discourse hampers efforts to find a solution to women's problems and create empowerment. ${ }^{45}$

\section{JUSTICE INITIATIVES TO CHALLENGE VIOLENCE}

CRSV crimes in the DRC have gained a tremendous amount of attention from international actors. Several international organizations, INGOs and donor countries provide assistance to fund and manage projects to challenge CRSV crimes. These projects are mainly focused on improvements in the legal system in accordance with the dominant discourse that supports state capacity building to abolish violence against women.

In order to challenge CRSV crimes through the legal system in the DRC, international actors first work on improving knowledge of the law. With regard to this, projects are maintained at both local and national levels. On a local level, sensitization sessions are organized for local communities. Due to a lack of education, local communities in rural areas do not have enough information about the legal system, and long-lasting corruption within the DRC state authorities has created distrust of formal mechanisms. ${ }^{46}$ Moreover, due to the stigmatization and shame associated with CRSV, survivors tend to remain silent. They are often afraid to speak about their experiences due to the fear of social exclusion. ${ }^{47}$ Thus, without informing local communities about legal processes, creating trust in the justice system and abolishing stigmatization, survivors will be unwilling to bring their cases to the legal authorities. This hinders legal institutions' ability to operate and challenge CRSV crimes. Sensitization is therefore crucial to increase the denunciation of such crimes.

Several international initiatives are working on programmes to sensitize local

\footnotetext{
45 O. Ohambe, J.B.B. Muhigwa and B.M. Wa Mamba, 'Women's Bodies as a Battleground: Sexual Violence against Women and Girls during the War in the Democratic Republic of Congo,' https://repositories.lib.utexas.edu/bitstream/handle/2152/4949/4053.pdf (accessed 3 April 2018).

$46 \mathrm{~J}$. Freedman, Gender, Violence and Politics in the Democratic Republic of Congo (Surrey: Ashgate, 2015).

${ }^{47}$ Bosmans, supra $\mathrm{n} 22$.
} 
communities regarding CRSV crimes. They include the UN Development Programme (UNDP), the UN Joint Human Rights Office (UNJHRO), Lawyers without Borders (Avocat sans Frontière, or ASF) and the American Bar Association Rule of Law Initiative (ABA ROLI). These actors mainly organize sensitization sessions on human rights, women's rights, the importance of denunciating crimes and legal processes. ${ }^{48}$ Sensitization sessions are significant to create knowledge of the Congolese legal system. However, these sessions should not only focus on legal rights but also on socioeconomic opportunities in order to create an understanding of why 'empowerment' matters when we seek to promote legal accountability.

On a national level, international actors work with legal authorities to train them in the national and international law on CRSV crimes and to create a sensitive approach to such crimes and their survivors. This training is part of the objective of state capacity building to improve the legal system. UNJHRO provides training to judicial officers on reparation, protection measures, ethics and investigation techniques, together with changes in the national and international law. ${ }^{49}$ To build expertise among Congolese lawyers, ASF trains them on specific crimes and rights, such as CRSV crimes, socioeconomic rights, protection of human rights, crimes against humanity, torture, children's rights and protection of women detainees. ${ }^{50}$ Training on similar issues for lawyers and magistrates is organized by $A B A$ ROLI and the UNDP; the latter seeks to sensitize magistrates on CRSV crimes and to enhance the protection of survivors and witnesses. ${ }^{51}$ Improving legal knowledge among lawyers and magistrates and sharpening their sensitivity to CRSV crimes are essential to

\footnotetext{
${ }^{48}$ Sahin interview, UNJHRO officer, Goma, the DRC, 27 October 2015; UNDP, 'DR Congo: Legal Clinics Help Victims of Sexual Violence,' http://www.undp.org/content/undp/en/home/ourwork/ourstories/RDC-lutte-contre-violencessexuelles.html (accessed 3 April 2018); ASF, 'ASF in the DRC,' http://www.asf.be/action/fieldoffices/asf-in-the-democraticrepublic-of-congo/ (accessed 20 October 2016); American Bar Association, 'Rule of Law Programs in the Democratic Republic of Congo,' http://www.americanbar.org/advocacy/rule_of_law/where_we_work/africa/democratic_republic_congo /programs.html (accessed 3 April 2018).

${ }^{49}$ Sahin interview, UNJHRO officer, Goma, the DRC, 27 October 2015.

${ }^{50}$ ASF, supra $n 48$.

51 Sahin interview, UN officer, Goma, the DRC, 16 October 2015; Sahin interview, ABA ROLI officer, Goma, the DRC, 15 October 2015.
} 
strengthen state capacity to deal with such crimes. However, this training has no direct impact on challenging the gendered and socioeconomic dimensions of CRSV crimes.

In addition to improving the legal knowledge of local communities and legal authorities, international actors organize and support justice initiatives in the DRC. As part of state capacity-building efforts, justice initiatives are provided to support the legal system until necessary improvements are achieved for it to operate by itself. These initiatives began in order to bring justice closer to people who live in remote areas, who are severely affected by the conflict and who do not manage to reach big cities, where the only legal institutions are, in order to receive justice. In response, international organizations and INGOs started to operate legal aid clinics or support the local legal aid clinics to arrange legal representation for survivors, as well as mobile hearings to actualize the legal process in remote areas.

Legal aid clinics are significant because they provide legal assistance and representation to a large group of people. By partly dealing with the economic obstacles faced by survivors, the clinics' free legal services are integral to achieving access to justice. Also, through the decentralization offered by legal aid clinics, survivors who live in remote areas can benefit from legal assistance provided by international and national actors. ASF financially supports bar associations to provide free legal support for survivors of any transgressions. ${ }^{52}$ ABA ROLI operates several legal aid clinics in North Kivu, South Kivu and Maniema provinces. ${ }^{53}$ Similar to previous international efforts, legal aid clinics mainly aim to improve state capacity and continue to respond to CRSV crimes through a state-centred approach.

Most of the legal aid clinics work with hospitals and other local NGOs as part of a holistic approach. Legal assistance is supplemented by medical, psychological and socioeconomic support for the survivors. Several hospitals, such as HEAL Africa and

52 Sahin interview, Goma Bar Association, Goma, the DRC, 27 October 2015.

${ }^{53}$ American Bar Association, supra $\mathrm{n} 48$. 
Kyeshero Hospital in North Kivu, and Panzi Hospital in South Kivu, offer free medical and psychological treatment. Furthermore, socioeconomic support is offered to women survivors of CRSV crimes in order to create skills in small business management. The UNDP supports multipurpose community centres in North Kivu to provide economic training in sewing, basket making, cattle breeding, baking and commercial gardening. In an interview, an UNJHRO officer confirmed that economic training programmes supported by the organization support similar activities. ${ }^{54}$ Through these holistic responses, there is a certain level of engagement with the medical, social and economic needs of Congolese women. However, organizations administering these programmes are usually unable to reach out to Congolese women on a large scale and are prone to narrowing their responses to the individual level, thereby neglecting systemic issues of women's status in general.

Mobile hearings are another justice initiative supported by international actors, with the aim of state capacity building to challenge insecurities and CRSV. There are a limited number of legal institutions in the DRC and they only operate in big cities. Ongoing conflict continues to create high numbers of CRSV survivors, especially in remote areas where access to justice is difficult. The DRC legal system recognizes mobile hearings if the area where atrocities happened is remote, if there are problems related to finance and security for survivors to travel to big cities, or if the number of survivors is too high to expect them all to travel to attend trials. ${ }^{55}$ However, the DRC legal authorities were not able to operate mobile hearings due to a lack of financial resources. Their operation only became possible after 2004 with the resources provided by international actors, ${ }^{56}$ who promoted mobile hearings specifically for CRSV crimes in conflict contexts as an effective way of reaching survivors in remote areas.

Based on the information provided in this section, we now analyze whether

\footnotetext{
54 Sahin interview, UNJHRO officer, Goma, the DRC, 27 October 2015.

55 Law No. 299/79, the Code of the Organization and Jurisdiction of Courts.

${ }^{56}$ American Bar Association, supra $\mathrm{n} 48$.
} 
international assistance and justice initiatives are able to provide solutions to the gendered and socioeconomic causes and impacts of CRSV crimes, or whether they continue to reshape gendered power relations. Although important legal improvements are needed in the DRC, international assistance largely does not deal with the gendered and socioeconomic dynamics of CRSV crimes. Sensitization sessions are valuable in order to break stigmatization and improve the legal consciousness of local communities, but they do not create socioeconomic awareness for local communities. Furthermore, although projects such as training judicial officers and operating legal aid clinics and mobile hearings are important to improve access to justice and the legal system, they do not deal with preventing CRSV crimes or working on their socioeconomic consequences. While medical and socioeconomic supports deal with CRSV crimes in a wider context, these are not at the centre of international assistance and are mainly provided to CRSV survivors rather than to Congolese women in general. In addition, the economic skills taught to women survivors focus chiefly on jobs traditionally associated with females and discourage a broadening of aspirations.

By not including Congolese women in general in these interventions, the prevention aspect is lost and the agenda is set to intervene only when women become 'victims.' Milli Lake and colleagues argue that most organizations have focused largely on CRSV and thus limit the experience of Congolese women when considering whether they can benefit from the assistance or not. ${ }^{57}$ Therefore, it is difficult to state that international assistance to challenge CRSV crimes is effective in dealing with the gendered dynamics and socioeconomic consequences of violence. This is not to suggest that current initiatives are unnecessary, but to highlight the importance of diversifying the understanding and approach to CRSV crimes on a regional level in order to appreciate why lasting impact is more achievable when women's voices are heard - not only when they are survivors, but long

${ }^{57}$ M. Lake, I. Muthaka and G. Walker, 'Gendering Justice in Humanitarian Spaces: Opportunity and (Dis)empowerment through Gender-Based Legal Development Outreach in the Eastern Democratic Republic of Congo,' Law and Society Review 50(3) (2016): 539-574. 
before that as well.

\section{WHAT WOMEN WANT BEFORE JUSTICE}

Espe, a young Congolese woman and CRSV survivor in Luanda, explained why she chose to live in a particular neighbourhood in the city:

I didn't want to run the chances of being recognized. Here I am a Langa [Congolese], but no one knows me, no one knows my story, people still give me work, and I can feed myself and send money to my parents. I don't know if I would be able to have a normal job back home. I wash clothes and iron, it's not much, but better than the other options. ${ }^{58}$

Espe's story highlights that international assistance based on justice initiatives in the DRC has failed to contribute to women's socioeconomic empowerment. This failure may have occurred because Congolese women's needs and expectations of justice initiatives and international assistance are inherently different from what is provided. The pursuit of gender equality and the need to challenge legal institutions to develop home-grown jurisprudence require African legal feminists to engage with local legal dynamics and expand feminist work in the regional context. ${ }^{59}$

Women's input as agents of change is missing from how their role in the DRC is seen. While Congolese women are kept from decision-making positions by both cultural influences and their limited access to justice, experiences on the ground are defined by the marginalized position in which they find themselves. Looking at socioeconomic rights within a gendered analysis of security, justice and economic development opens a critique of the current mechanisms of international actors, which promote discriminatory practices against women by deciding which type of violence is worthy of intervention and how local support is

\footnotetext{
${ }^{58}$ Kula interview, Congolese migrant woman, Luanda, Angola, 19 July 2016.

59 African Gender Institute, 'The Status of Legal Feminism in Africa: Gains and Limits,' http://www.agi.ac.za/sites/default/files/image_tool/images/429/gender_studies/gws_teaching_africa/g ender_law/the_status_of_legal_feminism_in_africa.pdf (accessed 3 April 2018).
} 
offered. This begs the question of whether it is a condition of intervention to overshadow local concerns around violence, or whether it is a natural political development to address what donors want to finance. Both create serious limitations to women's position and the role they are allowed to fulfil within decision-making challenges. If donors decide and in essence control where money is allocated, therefore pushing the agenda regarding what we should care about, is it then correct to state that these agendas fuel a vicious cycle of mismanagement? Elliot Berg argues that in a broader context, it too often happens that the requirement of a rapid and effective implementation of programmes drives donors to adopt policies that are detrimental to the development of local capacities. ${ }^{60}$ This perpetuates the notion that development work and its agenda has to be led by the global North and undermines progress towards truly sustainable development in the global South, in this case the DRC.

Improving the justice system in the DRC is not only about challenging CRSV crimes and promoting access to justice for Congolese people, but also about how international actors contribute to what is presented as the Congolese experience. The very notion that the DRC is the 'rape capital of the world' contributes to the conversation and reflections in the region. International assistance, with an emphasis on women's access to rights, tends to focus on the conflict setting but not on the everyday experiences, which cannot only be defined by the socioeconomic consequences of violence.

Furthermore, the idea that women's oppressions or limitations are rooted in violence and patriarchal norms limits the knowledge created about Congolese women's experiences, as men are reduced to perpetrators and international actors feel the need to intervene by similarly reducing women's struggle to a political discourse. However, C.N. Himonga and M.L. Munachonga state that legal reforms and women's access to rights must go hand in hand with the legal education of women, their economic access and the understanding of

${ }^{60}$ E. Berg, 'Dilemmes dans les stratégies d'aide,' Revue d'Économie du Développement 4 (1997): 83-100. 
customary practices with cultural reform when they seek legal solutions. ${ }^{61}$ This means that while intervening in conflict regions is necessary, women's roles need to be considered when international actors fund their projects. Reducing women's 'worthy' experience to that which is experienced in conflict limits their ability to participate in long-standing legal solutions. While most international actors do not assume an active role in improving women's economic well-being, it is important to understand the imbalance and economic instability that occurs when women are identified only as survivors of CRSV. The nature and intensity of the consequences of this violence, such as social exclusion, trauma and lack of representation and economic safety, mean that the variable between violence and dependency increases the significance of having a system that truly works for women.

In addition, international actors' dominant role in identifying what Congolese women should talk about impedes the agency of women. Aniese, a Congolese woman who migrated to Angola, stated that 'the only positive part of me being away from my home is that here there are no INGOs telling me what I should talk about.. ${ }^{62}$ In terms of the international assistance provided for promoting legal systems in the DRC, she said:

We [Congolese women] do not only want justice, but we also want to be heard. All they [international actors] know is Congolese women are raped, all they mention is how unsafe we are, but they don't mention how we fight, how every day we still have to go to the markets and sell. I got tired of being a victim. I wasn't a victim because I had to wake up every day, there was no one holding my hand, or telling me things would get better, so why would I want to be a victim $?^{63}$

Similarly, local communities are often willing to denounce perpetrators and

${ }^{61}$ C.N. Himonga and M.L. Munachonga, 'Rural Women's Access to Agricultural Land in Settlement Schemes in Zambia: Law, Practice, and Socio-Economic Constraints,' Third World Legal Studies 10 (1991): 59-74.

62 Kula interview, displaced refugee/migrant, Luanda, Angola, 23 July 2016.

63 Ibid. 
participate in formal court proceedings although their priority may not be seeking justice. Participating in court proceedings presents an opportunity for local communities to make their voices heard. A Congolese women's activist stated that women were eager to attend proceedings for the Minova trials because they saw it as an opportunity to communicate with state officers and explain their problems. ${ }^{64}$ During the testimonies, women urged state officials and international organizations to improve their economic situation and the provision of medical assistance and access to education for their children. ${ }^{65}$ Although criminal courts cannot provide an answer to these demands, they are seen by Congolese women as platforms helping them to reach out to national and international authorities. Therefore, women's priorities are reflected in the way women survivors conceptually approach legal institutions. There is an obvious need for Congolese women to be heard and to create changes for their lives, and they often use legal institutions to voice their needs and expectations.

Research on local communities in eastern DRC shows that their priorities are peace (51\%), security (34\%), money (27\%), education (26\%) and food and water (26\%). ${ }^{66}$ Notably, justice (2\%) and reconciliation (1\%) received comparatively small proportions of the total responses. While international actors mainly focus on access to justice, for most local women it is not a priority. Divine, a Congolese woman living in North Kivu, stated that justice is useful, but psychological assistance I have received was more effective. ${ }^{167}$ In the same vein, Miracle, a Congolese woman living in South Kivu, felt that 'what is more important I

\footnotetext{
${ }^{64}$ For more on the Minova trials, see, Human Rights Watch, 'Justice on Trial: Lessons from the Minova Rape Case in the Democratic Republic of Congo,' https://www.hrw.org/report/2015/10/01/justice-trial/lessons-minova-rape-case-democratic-republiccongo (accessed 4 April 2018).

65 Sahin interview, women's rights activist, North Kivu, the DRC, 21 October 2015.

${ }^{66}$ P. Vinck, P. Pham, S. Baldo and R. Shigekane, 'Living with Fear: A Population-Based Survey on Attitudes about Peace, Justice and Social Reconstruction in Eastern Democratic Republic of Congo,' 2008, https://www.ictj.org/sites/default/files/ICTJ-DRC-Attitudes-Justice-2008-English.pdf (accessed 3 April 2018).

${ }^{67}$ Sahin interview, Congolese woman, North Kivu, the DRC, 21 December 2015.
} 
guess is social integration and income generation activities. ${ }^{168}$ Therefore, instead of strong legal institutions, medical, educational and financial promotion is usually prioritized. This does not mean that justice is not important, but that Congolese women have other priorities before justice.

For Congolese women, integrity in how they care for their families is as important as having access to legal rights. As legal aid clinics and other justice initiatives fail to address the need for immediate access to change and economic stability, Congolese women seek alternative survival strategies. Vaghen Masika, a resident in Kanyabayonga, stated that Congolese women who have lost their parents 'have to fend for themselves in many ways to survive. ${ }^{69}$ She told how her neighbour has turned to sex work in order to afford to eat and has forced her children into the sex trade as well. But even so, she said, 'the proceeds were still not enough for survival. ${ }^{\cdot 70}$

Another consequence of international actors' lack of engagement with the socioeconomic consequences of violence is that many women who fall outside the scope of international assistance - and therefore cannot benefit from it - fabricate cases of CRSV as a survival strategy. In the context of a corrupt judiciary, widespread poverty and the decreasing stigma associated with rape, the focus on CRSV as a particularly serious crime seems to be increasingly associated with allegations of rape as an income-earning strategy. Moreover, the abundant resources earmarked by international organizations for various services to rape survivors, in combination with rampant poverty, have fostered a situation in which destitute women who are not exposed to CRSV crimes present themselves as rape

\footnotetext{
68 Sahin interview, Congolese woman, South Kivu, the DRC, 26 November 2015.

${ }^{69}$ Merveille Kavira, 'After Years of Conflict, Displaced Female DRC Residents Seek Trade Skills to Avoid Sex Work,' Global Press Journal, 12 March 2017, https://globalpressjournal.com/africa/democratic-republicofcongo/teen-turns-desperate-measuressurvive-displaced-person-drc/ (accessed 3 April 2018).

70 lbid.
} 
survivors in order to access services and opportunities. ${ }^{71}$ While the aim of international assistance is to provide support to women and improve gender equality, narrowly implemented strategies have contributed to claiming victimhood for Congolese women, which reinforces dominant norms and constructions around gender roles.

It is therefore notable that women rarely find spaces to define their own needs when international assistance to survivors of sexual violence crimes is implemented in the eastern DRC. Despite the expressed needs and expectations of Congolese women, international actors emphasize visible acts of violence rather than the ongoing struggles of women in everyday life due to gendered and political economy dynamics. Although justice initiatives supported by international assistance are valuable, international actors need to diversify their work in accordance with the socioeconomic needs of Congolese women. However, international organizations, INGOs and donor countries do not necessarily engage with these dynamics due to the difficulties of changing international engagements in the DRC and the 'Congolese experience,' as conceptualized in the global North, that all women are 'victims' who need others to advocate for them.

\section{CONCLUSION}

CRSV crimes need to be reconceptualized through recognition of the socioeconomic consequences of violence. Any analysis that does not consider these consequences renders itself ineffective in conceptualizing the complexity of the relationship between gender, violence and economic and legal structures. However, CRSV crimes are mainly defined as a problem for security by international actors that lack a localized analysis of gender.

Thus, the policies and projects to challenge these acts of violence are shaped in accordance with this dominant discourse, and improving state capacity and strengthening

\footnotetext{
${ }^{71}$ M. Eriksson Baaz and M. Stern, 'The Complexity of Violence: A Critical Analysis of Sexual Violence in the Democratic Republic of Congo (DRC),' Sida Working Paper on Gender-Based Violence (2010).
} 
legal institutions are prioritized as solutions. Despite important legal improvements for the DRC, international assistance mainly does not respond to local women's needs and therefore these issues continue to exist for Congolese women. Thus, international assistance fails to engage with women's lived experiences.

The struggle of Congolese women is viewed through the lens of western norms, which ignores their position within their communities, their roles as caregivers and providers, and their search for justice. CRSV crimes tend to be interpreted as (mostly) physical violence, thus failing to address the injustices based on gender and identity. This is not to say that trauma, stigma and other psychological aspects of being a survivor are entirely ignored, but rather that they receive less focus than they should. In talking to women who have experienced CRSV or interacted with survivors, what stands out is the lack of cultural understanding of stigma. The complex narrative on culture and psychology with regard to surviving violence is something that is not only lacking within the context of the DRC, but also too complex to navigate in limited legal and socioeconomic contexts. It is something that should be explored in an in-depth analysis and engagement in this region.

Improving the justice system in the DRC, however, is not only about challenging CRSV crimes and promoting access to justice for Congolese people, but also about how international actors contribute to what is presented as the 'Congolese experience' and the psychology behind it. International actors' dominant role in identifying what Congolese women should talk about hampers the active agency of women in this region. Congolese women have expressed their need to be heard by national and international authorities; for them not only to listen but to truly understand what they actually need from them. While Congolese women's priorities are focused on economic resources, access to education and food and water, international actors promote a western-based legal system which is incapable of addressing these priorities. As international assistance fails to acknowledge these needs, Congolese women often seek alternative survival strategies. Therefore, the current international focus on CRSV crimes creates a considerably narrow response to what 
Congolese women need and expect by perpetuating gendered and economic issues and undermining their active agency.

If we are to acknowledge women's role in peace processes, we have to acknowledge every aspect of their contribution to current crises, including their position in shaping the conversation around the gendered nature of economic development. The current discourse also shows limited exploration of the relationship between donor involvement, power relations and economic development, and emphasizes projects catering to women's participation without addressing their political representation as a marginalized group within the public sphere. In reconceptualizing interventions in the DRC, dominant narratives of adding women without acknowledging their agency or economic needs should be challenged. If the experiences of women are shared only to convey the narratives in contemporary feminist discourse, then the focus on violence should shift to peacebuilding and women's participation on the ground. Once the focus of international actors is no longer on the act of CRSV, but rather on what the actual needs of women are, then perhaps women will truly gain a voice in matters that affect them the most. If international intervention is to empower women's lives and improve access to justice, funding these projects should require the involvement of local women and other leading actors directly involved with these communities. Donor spending is influenced by what is reported and vice versa, which contributes to an unending cycle of stigmatized development contribution. ${ }^{72}$ The agenda should focus not only on producing new stories of the gendered violence that women experience, but also on producing narratives on the economic impact it has on their livelihoods. If as a result of gendered violence women have to work as sex workers and we only focus on the act of 'justice,' are we not failing women inherently by dictating the type of conversation they should be having? Although we acknowledge that justice initiatives contribute to the political economy of women's position, there are limitations in the current

\footnotetext{
72 Nadine Puechguirbal, 'Gender Training for Peacekeepers: Lessons from the DRC,' International Peacekeeping 10(4) (2003): 113-128.
} 
implementation in the global South. Further exploration is warranted within a separate academic project.

\section{BIBLIOGRAPHY}

\section{Primary Sources}

The United Nations Security Council, Security Council resolution 1325 (2000) [on women and peace and security], S/RES/1325 (2000).

The United Nations Security Council, Resolution 1820 (2008) adopted by the Security Council at its 5916th meeting. S/RES/1820 (2008).

The United Nations Security Council, Resolution 1889 (2009) adopted by the Security Council at its 6195th meeting. S/RES/1888 (2009).

The United Nations Security Council, Resolution 1888 (2009) adopted by the Security Council at its 6196th meeting. S/RES/1889 (2009).

The United Nations Security Council, Resolution 1925 (2010) adopted by the Security Council at its 6324th meeting. S/RES/1925 (2010).

The United Nations Security Council, Resolution 1960 (2010) adopted by the Security Council at its 6453th meeting. S/RES/1960 (2010).

The United Nations Security Council, Resolution 2106 (2013) adopted by the Security Council at its 6984th meeting. S/RES/2106 (2013).

The United Nations Security Council, Resolution 2122 (2013) adopted by the Security Council at its 7044th meeting. S/RES/2122 (2013).

\section{Secondary Sources}


ABA ROLI, Rule of Law Programs in the Democratic Republic of Congo, http://www.americanbar.org/advocacy/rule_of_law/where_we_work/africa/democratic_republ ic_congo/programs.html, (accessed on 27 April 2017).

The African Gender Institute, The Status of Legal Feminism in Africa: Gains \& Limit, http://agi.ac.za/teaching-material/status-legal-feminism-africa-gains-limits (accessed on 20 November 2016).

Ahikire, J. 'African feminism in context: Reflections on the legitimation battles, victories and reversals', Feminist Africa, 19(2014).

Akosua Adomako, A., Beoku-Betts, J., and Mary J. Osirim, M. J., 'Researching African Women and Gender Studies: New Social Science Perspectives.' African and Asian Studies 7 (2008): 327-341.Aniekwu, N.I., 'Converging Constructions: A Historical Perspective on Sexuality and Feminism in Post-Colonial Africa', African Sociological Review, 10(2006): 143160.

ASF, ASF in the DRC, http://www.asf.be/action/field-offices/asf-in-the-democratic-republicofcongo/ (accessed on 20 October 2016).

Atanga, L. 'African Feminism', in Gender and Language in Sub-Saharan Africa: Tradition, Struggle and Change, eds. Lilian Lem Atanga, Sibonile Edith Ellece, Lia Litosseliti, Jane Sunderland, (Amsterdam: John Benjamins Publishing Company, 2013).

Autesserre, S., The Trouble with the Congo: Local Violence and the Failure of International Peacebuilding, (Cambridge: Cambridge University Press, 2010).

Berg, E., 'Dilemmes dans les stratégies d'aide', Revue d’Economie due Développement, 4 (1997), pp. 83-100.

Bjorkhaug, J. and Boas, M. Men, women, and gender-based violence in North-Kivu, DRC. 2014, FAFO. 
Bosmans, M. 'Challenges in Aid to Rape Victims: the Case of the Democratic Republic of the Congo', Essex Human Rights Review, 4(2007): 1-12.Campbell, J.C. and Dienemann, J. D. 'Ethical issues in research on violence against women'. In C. M. Renzetti, J. L. Edleson, \& R. K. Bergen (Eds.), Sourcebook on violence against women(Newbury Park, CA: Sage, 2000): 57-72.

Charlesworth, H. and Chinkin, C., The Boundaries of International Law: A Feminist Analysis (Manchester University Press, 2000).

Chilisa, B. and Ntseane, G. 'Resisting dominant discourses: implications of indigenous, African feminist theory and methods for gender and education research', Gender and Education, 22(2010).

Christie, R., 'Critical Voices and Human Security: To Endure, to Engage or to Critique,' Security Dialogue 41 (2010): 169-190.

Clifford, C. Rape as a Weapon of War and its Long-term Effects on Victims and Society. Presented at the 7th Global Conference Violence and the Contexts of Hostility, 2008, Budapest, Hungary.

Cohen, D.K., Green, A.H. and Wood, E.J. 'Wartime Sexual Violence Misconceptions, Implications, and Ways Forward', The United States Institute of Peace, 2013, Special Report 323

Collins, P. H., 'Gender, Black Feminism, and Black Political Economy,' The ANNALS of the American Academy of Political and Social Science 568 (2000): 41 - 53.

Duffield, M., ‘Global Civil War: The Non-Insured, International Containment and PostInverventionary Society,' Journal of Refugee Studies 21 (2008): 145-165.

El-Bushra, J. 'Feminism, Gender, and Women's Peace Activism', Development and Change, 38(2007): 131-147. 
Erikkson Baaz, M. and Stern, M. Sexual Violence as a Weapon of War? Perceptions, Prescriptions, Problems in the Congo and Beyond, (London: Zed Books, 2013).

Eriksson Baaz, M. and M. Stern, The Complexity of Violence : A critical analysis of sexual violence in the Democratic Republic of Congo (DRC), (The Nordic Africa Institute and SIDA, 2010).

Fontes, L.A. 'Ethics in Violence against Women Researh: The Sensitive, the Dangerous, and the Overlooked', Ethics and Behaviour, 14(2004): 141-174.

Freedman, J. Gender, Violence and Politics in the Democratic Republic of Congo. (Surrey: Ashgate, 2015).

Grauerholz, L. 'An ecological approach to understanding sexual revictimization: Linking personal, interpersonal, and sociocultural factors and processes' Child Maltreatment, 5(2000): 5-17.

Hagen, K.T. and Yohani, S.C. 'The Nature and Psychosocial Consequences of War Rape for Individuals and Communities', International Journal of Psychological Studies, 2(2010), p. 14-25.

Hettiarachchi, S. H. 'Gender Mainstreaming in Post-Conflict Countries: An Analysis of PostConflict Reconstruction Process in Some Selected Countries', International Conference on Gender and the Law: Limits, Contestations and Beyond, (Turkey, 2015).

Hettne, B., 'Development and Security: Origins and Future,' Security Dialogue 41 (2010): 3152.

Himonga, C. N. and Munachonga, M. L. 'Rural Women's Access to Agricultural Land in Settlement Schemes in Zambia: Law, Practice, and Socio-Economic Constraints', Third World Legal Studies, 10 (1991): 59 - 74.

Holstein,J.A and Gubrium, J.F. 'The Active Interview.' In: D. Silverman, ed. 2004. 
Qualitative research: Theory, method and practice (2nd Edition). London: SAGE. pp. 141161.

Hoogensen G. and K. Stuvoy, 'Gender, Resistance and Human Security’, Security Dialogue, 37(2006): 207-228.

Hudson, H. 'Doing' Security As Though Humans Matter: A Feminist Perspective on Gender and the Politics of Human Security', Security Dialogue, 36(2005): 155-174.

Human Rights Watch, Soldiers Who Rape, Commanders Who Condone: Sexual Violence and Military Reform in the Democratic Republic of Congo, 2009, https://www.hrw.org/report/2009/07/16/soldiers-who-rape-commanders-whocondone/sexualviolence-and-military-reform, (accessed on 27 October 2016). ICTJ, 'What is Transitional Justice', https://www.ictj.org/about/transitional-justice (accessed on 25.09.2017).

International Alert Ending the Deadlock: Towards a new vision of peace in eastern DRC, 2012, http://www.international-

alert.org/sites/default/files/publications/201209EndingDeadlockDRC-EN.pdf (accessed on 27 October 2016).

International Crisis Group, Congo: No Stability in Kivu despite a Rapprochement with Rwanda, 2010, Report no 165.

Kavira, M., After Years of Conflict, Displaced Female DRC Residents Seek Trade Skills to Avoid Sex Work, Global Press Journal , 12th March 2017, https://globalpressjournal.com/africa/democratic-republic-of-congo/teen-turnsdesperatemeasures-survive-displaced-person-drc/ (accessed 15 March 2017).

Kelly, L., 'War against Women: Sexual Violence, Sexual Politics and the Militarised State' in States of Conflict, Gender, Violence and Resistance, eds. S Jacobs, R Jacobson and J Marchbank (London: Zed Books, 2000). 
Klosterboer, B. and L. Hartmann-Mahmud, 'Difficult to Reair: Applying African Models of Transitional Justice to Peace and Restoration Prospects in the Democratic Republic of the Congo', African conflict and Peacebuilding Review, 3(2013): 56-80.

Lake, M., Muthaka, I. and Walker, G., 'Gendering Justice in Humanitarian Spaces:

Opportunity and (Dis)empowerment Through Gender-Based Legal Development Outreach in the Eastern Democratic Republic of Congo'. Law \& Society Review, 50(2016): 539-574.

Lee, R.M. and C.M. Renzetti, 'The problems of researching sensitive topics: An overview and introduction'. American Behavioral Scientist, 33(1990): 510-528.

Mbambi, A. M., and Faray-Kele, M., 'Gender Inequality and Social Institutions in the DR Congo', Peace Women (April - December 2010).

Mikell, G. 'Introduction', in African Feminism: The Politics of Survival in Sub-Saharan Africa, (ed.) G. Mikell, Philadelphia: University of Pennsylvania Press, p. 1-53.

Mohanty, C. 'Under Western Eyes: Feminist Scholarship and Colonial Discourses', in Third World Women and the Politics of Feminism, eds. Chandra Mohanty, Ann Russo and Lourdes Torres, (Indianapolis: Indiana University Press, 1991).

Montell, F. 'Focus Group Interviews: A New Feminist Method' NWSA Journal, 11(1999): 4471.

Ní Aoláin, F. 'Women, Security, and the Patriarchy of Internationalized Transitional Justice ', Human Rights Quarterly, 31( 2009): 1055-1085.

Ohambe, O., Muhigwa, J.B.B. and Wa Mamba, B. M., 'Women's bodies as a battleground: sexual violence against women and girls during the war in the Democratic Republic of Congo'. In: M.Galloy, N.Snow and C.Hall, eds. Réseau des Femmes pour un Développement Associatif (RFDA), Réseau des Femmes pour la Défense des Droits et la Paix (RFDP) and International Alert (2004). 
Operational Guidelines for Institutional Review Boards, 2007,

https://www.moh.gov.sg/content/dam/moh web/Publications/Guidelines/Human\%20Biomedi cal\%20Research/2007/IRB\%200perational\%20Guidelines 14-12-07 formatted.pdf (accessed on 21 October 2017).

Otto, D. and G. Heathcote, G., Rethinking Peacekeeping, Gender Equality and Collective Security: An Introduction, in: Otto, D., Heathcote, G. (Eds.), Rethinking Peacekeeping, Gender Equality and Collective Security. (Hampshire, UK: Palgrave Macmillan, 2014), pp. $1-20$.

Oyewumi, O., 'Conceptualizing Gender: The Eurocentric Foundations of Feminist Concepts and the Challenge of African Epistemologies' Jenda: A Journal of Culture and African Women (2002).

Puechguirbal, P., 'Gender training for peacekeepers: Lessons from the DRC', International Peacekeeping 10 (2003): 113-128.

Shepherd, L. 'Power and Authority in the Production of United Nations Security Council Resolution 1325 ', International Studies Quarterly, 52 (2008): 383-404

Sjoberg, L. 'Introduction', in Gender and International Security: Feminist Perspectives, (ed.) L. Sjoberg, (London: Routledge, 2010).

Taylor, V. 'From State Security to Human Security and Gender Justice ', Agenda: Empowering Women for Gender Equity, 59(2004): 65-70.

Tickner, J. A., 'Feminist Perspectives on Security in a Global Economy', in Globalisation, Human Security and the African Experience, (eds.) C. Thomas and P. Wilkin, (London: Lynne Rienner Publishers, 1999).

Tripp, A. M. 'Toward a Gender Perspective on Human Security', in Gender, Violence and Human Security: Critical Feminist Perspectives, (eds.) A. M. Tripp, M. M. Ferre and C. Ewig, 
(New York: New York University Press, 2013).

True, J., The Political Economy of Violence against Women (Oxford: Oxford University Press, 2012).

Turshen, M. 'The Political Economy of Violence against Women During Armed Conflict in Uganda', Social Research, 67(2000).

The UN, DRC: New Dawn in the Fight to End Sexual Violence and Child Recruitment and Use in Conflict, The Office of the Special Representative of the Secretary-General for Children and Armed Conflict. 2014.

https://childrenandarmedconflict.un.org/pressrelease/drc-new-dawn-in-the-fight-to-endsexual-violence-and-child-recruitment-and-use-inconflict/ (accessed on 03 June 2016).

UN Economic and Social Council, Resolution 2010/29, 2010, http://www.un.org/en/ecosoc/docs/2010/res\%202010-29.pdf (accessed on 10 march 2016).

UNDP, DR Congo: Legal clinics help victims of sexual violence, 2014, http://www.undp.org/content/undp/en/home/ourwork/ourstories/RDC-lutte-contreviolencessexuelles.html, (accessed on 24 June 2016). UNDP, UNDP supports the justice system in the DRC. 2013.

http://www.cd.undp.org/content/rdc/en/home/ourwork/democraticgovernance/successstories/ gouvjudchainejum/ (accessed on 24 June 2016).

UNDP, 'New Dimensions of Human Security. Human Development Report 1994', United Nations Development Programme, 1994.

Vinck, P., Pham, P., Baldo, S. and Shigekane, R., Living with Fear: A Populationbased Survey on Attitudes about Peace, Justice and Social Reconstruction in Eastern Democratic Republic of Congo, Joint Project between Human Rights Centre University of California, Berkeley, Payson Centre for International Development Tulane University and International Centre for Transitional Justice, 2008. 
WHO, 'Ethical and safety recommendations for researching, documenting and monitoring sexual violence in emergencies', 2007,

http://www.who.int/gender/documents/OMS Ethics\&Safety10Aug07.pdf (accessed on 21

October 2017) 